\title{
BIBILOGRAFI SEJARAH PANDEMI BLACK DEATH DI MESIR PADA ABAD KE 14 M
}

\author{
Ady Fauzi Rahmani \\ Madrasah Aliyah Persatuan Islam 68, Sukabumi \\ E-Mail: Adyrahmanie@gmail.Com
}

\begin{abstract}
The purpose of this research is to make an inventory and identify a number of publications that discuss the History of Pandemic in Egyptin the 14th century. The method used is the historical method. The result of this study is that the availability of bililiographic sources on the history of the Black Death pan demic in Egypt can be useful for seeing the continuity, parallelism, and comparison of the pandemic. To deal with a pandemic, a country needs to issue a policy in an emergency year while testing vaccines and drugs, until it is declared fit for use. In addition, another finding from this study is that social relations between communities greatlyaffecthuman strength in fighting a pandemic outbreak.
\end{abstract}

Keywords: Bibliography, Black Death, Egypt, Pandemic.

\begin{abstract}
ABSTRAK
Tujuan penelitian ini untuk menginventarisasi dan mengidentifikasi sejumlah publikasi yang membahas Sejarah Pandemi di Mesir pada abad ke 14. Metode yang digunakan adalah metode sejarah. Hasil penelitian ini adalah ketersediaan sumber bililiografis tentang sejarah pandemi Black Death di mesir dapat berguna untuk melihat kesinambungan, paralelisme, dan perbandingan pandemic. Untuk menghadapi pan demic negara perlu mengeluarkan Kebijakan dalam keadaan darurat thaun samb il menguji vaksin dan obatnya, sampai dinyatakan layak digunakan selain itu penemuan lainnya dari penelitian ini adalah hubungan sosial antar masyarakat sangat berpengaruh terhadap kekuatan manusia dalam melawan wabah pandemic.
\end{abstract}

Kata Kunci: Bibilografi, Black Death, Mesir, Pandemi.

\section{PENDAHULUAN}

Hari ini (tahun 2020),Indonesia dan hampir seluruh Negara-negara di dunia mengalami pandemi bernama Covid-19. Patut dicatat, fenomena pandemi sejatinya telah terjadi berulangkali sepanjang sejarah umat manusia. Berbagai catatan sejarah melaluiliterasitulis yang ada memberi informasi tentang hal itu (Butar-Butar, 2020). Pandemi sejatinya telah terjadi berulang kali sepanjang sejarah, hal ini sebagaimana telah tercatat dalam buku-buku sejarahyang menginformasikan tentangkapan dan dimana saja pandemi itu pernah terjadi, berapa jumlah orang yang meninggal dunia disebabkan pandemi itu, bagaimana respons masyarakat ketika itu, dan lain-lain. Bahkan, beberapa literatur tentang pandemi adakalanya ditulis karena memang telah terjadi dan menimpa dirinya atau kerabatnya. Misalnya, Ibn Hajar (w. 852 H/1448 M) yang kehilangan 3 putrinya dalam sebuah tragedi pandemi. Lalu Ibn al-Wardy (w. $749 \mathrm{H} / 1348 \mathrm{M}$ ) yang wafat dalam sebuah pandemiyang terjadidi Aleppo dan kawasan lainnya (sejak tahun $742 \mathrm{H}$ sampai tahun $749 \mathrm{H} / 1348 \mathrm{M}$ ). Lalu Taj ad-Din as-Subky (w.771 H/1369 M) yang wafat dalam salah satu peristiwa pandemi, danlain-lain. (Butar-Butar, 2020).

Kitâb al-Thibb, salah satu bab dalam Shahih al-Bukhârî, memuat kumpulan Hadistentanginformasi kesehatan umat Islam pada masa hidup Nabi Muhammad Saw. Hadisyang terhimpun dalam b ab tersebut kebanyakan terkait dengan preventive medicine (pengobatan pencegahan, atau althibb al-wiqấi),

* Copyright (c) 2021 Ady Fauzi Rahmani

This work is licensed under a Creative Commons Attribution-ShareAlike 4.0 International License.

Diterima: 11 October 2020; Direvisi: 31 Desember 2020 ; Disetujui: 2 Februari 2021 
Khazanah Pendidikan Islam, Vol. 3 No. 1: 1 - 9

Bibilografi Sejarah Pandemi Black Death di Mesir pada Abad ke $14 \mathrm{M}$

Ady Fauzi Rahmani

ketimbang pengobatan penyembuhan, (therapeutic medicine, atau al-thibb al-'ilaji). Metode pencegahannyaterbilang cukup maju, melihat tingkat pengetahuanilmiah yangada pada saatitu. Dalam Hadis-hadis itu tercantum perilaku dan upaya penyembuhan kepada penderita penyakit. Penanggulangan penyakit didasarkan, pada penyebab penyakit tersebut. Meskipun apa yang dipraktikkan tersebut tidak serta-merta dapat diterapkan tanpa melalui penelitian empirik, namun, gagasan dan prinsip dasar yang diajarkan oleh Nabi Muhammad Saw. tetap berlaku hingga kini, (Nurhayati, 2016).

Secara historis, a da tiga pandemi yang banyak memakan korban, yaiu (1) pandemi Justinian (abad ke-6 dan ke-7), (2) Kematian Hitam (abad ke-14 dan ke-18), dan (3) pandemi ketiga (1855-1959).(Lotfy, 2015). Penelitian ilmiah tentang Black Death $749 / 1348$ sebagian besar berfokus pada dampaknya di Eropa. Tetapi penelitian Michael W. Dols menunjukkan bahwa Black Death juga memiliki konsekuensi yang sangat buruk bagi populasi dan masyarakat di tanah Mediterania timur dan membunuh sepertiga hingga dua pertiga populasi Eropa. Pada saat yang ham pir bersamaan, terjadi pula epidemi pada sebagian besar Asia dan Timur Tengah, yang menunjukkan bahwa peristiwa di Eropa sebenarnya merupakan bagian dari pandemi multiregional. Jika termasuk Timur Tengah, India, dan Tiongkok, Maut Hitam telah merenggut sedikitnya 75 juta nyawa. Penyakit yang sama diduga kembali m elanda Eropa pada setiap generasi dengan perbedaan intensitas dan tingkatfatalitasyang berbeda hingga abad 1700 -an. Beberapa pandemi penting yang muncul kemudian antara lain Pandemi Italia (1629 - 1631), Pandemi Besar London (1665 - 1666), Pandemi Besar Wina (1679), Pandemi Besar Marseille (1720 - 1722), serta pandemi pada tahun 1771 di Moskwa. Penyakit ini berhasil dimusnahkan di Eropa pada awal abad ke-19, tetapi masih berlanjutpadabagianlain dunia (Afrika Tengah dan Oriental,Madagaskar, Asia, beber apa bagian Amerika Selatan) (Conrad, 1970). Namun, inventarisasi penelitian mengenai hal ini masih sangat kurang, diperlukannya inventarisir mengenai penyakit wabah Black Death kedalam satu wadah artikel yang memudahkan seseorang untuk mencari literature penelitian maupun pertimbangan perencanaan kebijakan serta menemukan solusiyang masih mumpuniuntuk diterapkan dimasa sekarang.

\section{METODE PENELITIAN}

Metode penelitian yang digunakan dalam penelitian ini adalah metode sejarah. Penelitian sejarah melalui empattahapan, yaitu heruristik, kritik, interpretasi dan historiografi. Heuristik bermakna mencari dan menemukan sumber sumber sejarah. Kritikadalah menguji sumber sejarah sehingga klayak dijadikan bahan rekonstruksi sejarah. Interpretasiadalah menganalisis dan mensintesis sumber sejarah yang telah dikritik Langkah terakhir adalah Historiografi, yaitu penulisan hasil dari penelitian sejarah (Thohir \& Sahidin, 2019) Sumber penelitiaan ini diperoleh dari buku bibliografis tentang pandemi di dunia Islam, yaitu Buku Kepustakaan Medis-Pandemik di Dunia Islam karya Arwin Juli Rakhmadi Butar-Butar (ButarButar, 2020). Dari buku tersebut diseleksi sumber yang membahas sejarah pandemi di Mesir pada abad ke 14 M. Sumber itu dikritik dan diinterpretasi dengan filsafat sejarah Thomas Kuhn (Kuhn \& Hawkins, 1963).

\section{HASIL DAN PEMBAHASAN}

\section{Hasil}

Penelitian ini menganalisis sejarah kedokteran pandemi dalam Islam dengan Pendekatan Kajian filsafat sejarah sains Thomas Kuhn (Kuhn, 1996), teori sejarah sains Islam Howard Turner serta Buku Sains and Islam Muzaffar Iqbal serta Kepustakaan Medis-Pandemik di Dunia 
Islam Arwin Juli Rakhmadi Butar-Butar. Buku Kepustakaan Medis-Pandemik di Dunia Islam berisi informasi sejumlah naskah-naskah manuskrip yang membahas tentang pandemi penyakit menular, khususnya yang dikenal dalam sejarah Islam dengan Tha'un. Melalui informasi naskah-naskah (manuskrip) yang pernah ditulis oleh para ulama dan dokter Muslim ini, tampak bahwa fenomena pandemi penyakit menular (pandemi) sejatinya telah ada dan berulang kali terjadi sepanjang sejarah umat manusia. (Butar-Butar, 2020).

Mengenai pandemi, banyak pertanyaan terkait penularan dan perilaku yang tepat dari kaum muslimin sepeerti saat mengalaminya. Tidak ada perawatan khusus untuk penyakitnya, tapi instruksi untuk perilaku pribadi. Salah satu hikmah dari tidak adanya perintah dan perawatan yang jelas adalah bisa diterjemahkan dengan kearifan lokal. Jika bentuknya perintah dan ditunjukan secara spesifik obatnya, maka tidak ada ruang berkreasi untuk para ilmuwan muslim. Jadi, teori medis tidak perlu mempertanyakan atau mengajukan rekonsliliasi dengan agama, tapi dapat langsung menginofrmasikan metode yang menerjemahkan tradisi islam (Ragab, 2012).

Menurut Thomas Kuhn, sejarah adalah sebuah repository yang dapat menghasilkan transformasi untuk menentukan citra sains. Ia memiliki dua tugas utama, (1) menetapkan oleh siapa dan pada saat apa fakta, dalil dan teori sains kontemporer itu ditemukan atau diciptakan (2) menguraikan dan menerangkan penumpukan teori sains lama yang menjadi kekeliruan, mitos, dan takhayul dengan teori sains modern. Fondasi ini memiliki pencapaian yang baru dan terbuka yang dikenal dengan istilah paradigma. Agar diterima, paradigma itu mesti dikampanyekan dengan persuasive communication. (Kuhn \& Hawkins, 1963)

Menurut Muzaffar Iqbal, dua cabang ilmu pengetahuan, (kedokteran dan astronomi) telah ada sejak zaman nabi. Ini membentuk tradisi sains dalam Islam. Sehingga, pada masa Abbasiyah, para ilmuwan menerjemahkan teks sains asing dengan melewati pengujian yang konstan dan detil, untuk kemudian diterima atau ditolak berdasarkan tes eksperimetal dan obeservasi (Blossfeld et al., 2014). Sayyed Nasr Nasr berpendapat bahwa Sejarah Sains Islam dimulai melalui hubungan sains Yunani dan Harrania, dan, yang paling penting melalui pengaruh India dan China, melewati Persia, secara langsung dibawa oleh pengunjung ke negeri negeri Islam. Warisan yang beragam ini menghasilkan khazanah intelektual yang lebih bersifat internasional, lintas budaya, dan melimpah dibandingkan warisan yang diterima oleh suatu peradaban tunggal masa sebelumnya (Bistara, 2020).

\section{Black Death}

Maut Hitam, disebut juga Pandemi Hitam atau Black Death, adalah suatu pandemi hebat yang pertama kali melanda Eropa pada pertengahan hingga akhir abad ke-14 (1347 - 1351). Black Death berasal dari atau dekat Tiongkok dan menyebar cara Jalur Sutra atau dengan kapal. Ini mungkin telah mengurangi dunia populasi dari sekitar 450 juta menjadi antara 350 dan 375 juta pada 1400. Pandemi melanda berbagai negara di Timur Tengah dan menyebabkan depopulasi yang serius dan perubahan permanen baik dalam struktur ekonomi maupun sosial. Saat menyebar ke Eropa Barat, penyakit tersebut masuk ke wilayah tersebut dari Rusia Selatan juga. Pada 1347, pandemi mencapai Alexandria di Mesir, mungkin melalui perdagangan pelabuhan dengan Konstantinopel, dan pelabuhan di Laut Hitam. (Lotfy, 2015). 
Khazanah Pendidikan Islam, Vol. 3 No. 1: 1 - 9

Bibilografi Sejarah Pandemi Black Death di Mesir pada Abad ke $14 \mathrm{M}$

Ady Fauzi Rahmani

\section{Kitab, Buku dan Artikel tentang Dampak Black Death di Mesir}

\section{Kitāb al-sulūk lī-ma 'rifa duwal al-mulūk}

Al Maqrizi, Sejarawan terkenal Mesir pada masa Mamluk, menulis laporan yang paling penting tentang Black Death di Timur Tengah, meskipun dia tidak mengalaminya (DOLS, 1977). pada tahun $1347 \mathrm{M}$, pandemi penyakit yang "lebih buruk daripada yang pernah terlihat sebelumnya di dunia Islam" dimulai dengan sebuah kapal penuh dengan mayatyang hanyut ke Alexandria. Ada beberapa pelaut yang masih hidup; mereka meninggal segera setelahnya - dan pengalaman Mesir dengan Kematian Hitam dimulai (Lotfy, 2015) Black Death mencapai Mesir pada musim gugur tahun $748 \mathrm{H} / 1347 \mathrm{M}$ dan perlahan menyebar dataran rendah Mesir dimulai dari Mutiarram 749H/April 1348M. Epidemi ini mencapai puncaknya di bulan Sha'ban, Ramadan, and Shawwa1 749H/Oktober 1348 sampai dengan January 1349, dan berhenti pada pertengahan bulan Dzulqadah /awala Februari.' Kota pertama di Mesir yang terena pandemi adalah Alexandria, dari sini bisa diasumsikan bahwa pandemic ini telah ditularkan oleh perdagangan penting dari Crimea. (DOLS, 1977).

Dari Alexandria, Black Death menyebar ke seluruh Delta, megarah ke tenggara, sampai mencakup seluruh provinsi Buhairah. (DOLS, 1977). Mengarah ke timur, pandemic ini menuju privinsi Gharbiyyah. Di ibukotta provinsi Mahallah, di pusat Delta, kasus kematian sangat besar. Dalam konklusinya, Maqrizi mengatakan, pandemic ini tidak hanya mengenai manusia, tapi juga ikan laut, burung di langit, dan binatang buas. (DOLS, 1977) di Aleksandria pandemi mulai menewaskan ribuan orang. mengeruk orang sehari, dan korban tewas berlipat ganda menjadi dua ratus sehari. Saat pandemi mencapai puncaknya, ada pemakaman massal sebanyak tujuh ratus orang. (S. Borsch, 2016)

\section{Rihlah Ibnu Battuta}

Dalam Kitab Rihlah, Ibnu Battuta menyampaikan, ketika Ia tengah menikmati pertemuan dengan para ulama di Aleppo pada pertengahan 1348, datang para musafir dari selatan. Mereka membawa kabar tentang penyakityang merebak di Gaza, di perbatasan Mesir. Setiap hari lebih dari 1000 orang mati. Bisul atau pembengkakan yang panas muncul di paha, ketiak, atau kuduk, disertai mual, sakit di kepala, perut, dan kaki. Korbannya tak bisa tidur dan terus mengigau. "Apabila korban mulai meludahkan darah dan menampakkan gejala radang paru-paru, biasanya ia mati dalam beberapa jam,"(Batutah, 1987)

\section{Muqaddimah Ibnu Khaldun}

Dalam Muqaddimah, Ibnu Khaldun menulis bahwa pada pertengahan abad kedelapan Hijirah (empat belas masehi) peradaban Timur dan Barat dihinggapi pandemi pes yang menghancurkan bangsa-bangsa dan menyebabkan banyak sekali penduduk mati. Penyakit itu telah menelan peradaban-peradaban yang baik, serta menghapusnya sama sekali. ia menyerbu negara-negara yang telah berusia ianjut dan mencapai puncaknya yang paling jauh. Penyakit itu telah menguras kekuatan dan membatasi pengaruh mereka. Penyakit itu telah melemahkan kekuatan mereka. Keadaan mereka mendekati titik kehancuran dan kemusnahan. Dengan musnahnya ummat manusia,mundurlah peradaban di bumi. Kota dan pabrik hancur. Jalan raya dan rambu-rambunya musnah. Tempat tinggal dan rumah kosong. Negara dan kabilah menjadi lemah. Semua itu menyebabkan seluruh dunia yang didiami manusia berubah.(Khaldun, 1973 
hal ) . Dalam muqaddimah pula, Ibnu Khaldun menyampaikan pendapatnya, bahwa ilmu pengetahuan telah menerangkan pentingnya lahan kosong dan daerah yang sepi di antara "areal" peradaban, 'umran, supaya memungkinkan terjadi sirkuIasi udara. Ia melenyapkan kerusakan udara dan pembusukan yang disebabkan oleh udara setelah adanya kontak dengan makhluk hidup, dan mendatangkan udara yang bersih. Karenanya pula, pandemi yang terdapat di kota-kota yang banyak penduduknya lebih banyak daripada yang terdapat di tempat lain, seperti Mesir di Timur, dan Fez di Magribi. (Khaldun, 1973).

\section{Badzl Maunfi Fadhli Thaun karya Ibnu Hajar al Asqalani}

kitab Badzl al-Mā'un fī Fadhl ath-Thāūn karya Ibnu Hajar al Atsalani, yang membahas membahas 3 hal, yaitu: pertama, tentang penyakit Tha'un. Kedua, tentang obat-obatan. Ketiga, tentang kepustakaan penyakit Tha'un.(Butar-Butar, 2020) Kitab ini ditulis Ibnu Hajar berdasarkan permintaan dari sahabat-sahabatnya, untuk menyusun dan mengumpulkan hadits nabi berkaitan dengan thaun yang terjadi waktu itu. Badzlu secara bahasa artinya mengeluarkan tenaga sekuat-kuatnya, adapun al-ma'un artinya pertolongan. Badzlul maun bisa diartikan mengeluarkan kemampuan sekuat tenaga untuk mendapatkan pertolongan. Pertolongan ini bisa diartikan manusiawi, mencari obat, atau mengisolasi diri, bisa juga ampunan dari Allah Swt. Fadhli bisa diartikan keutamaan, manfaat. Sedangkan thaun adalah sisa-sisa azab berupa penyakit menular, yang diturunkan Allah kepada umat terdahulu yang membangkang kepada risalah Allah. Artinya meski thaun itu adalah sesuatu yang jelek dan menyakitkan, tapi selalu ada hikmah serta keutamaan dibalik kejelekan tersebut. Beliau membagi kitab setebal 410 halaman ini menjadi lima bagian. Bagian yang pertama mengenai pengenalan thaun, bab kedua tentang hakikat thaun dalam al Quran dan hadits, bab ke tiga tentang kedudukan syahid bagi yang terkena thaun, bab keempat adalah peristiwa thaun yang pernah terjadi dan cara orang beriman meyikapinya saat itu, dan bab ke lima membahas langkah-langkah praktis yang dilakukan seorang muslim, ketika di wilayahnya terjadi thaun. (Asqalani, 2020).

Pada kitab ini, belliau merekam kejadian thaun yang terjadi pada masanya, yang beliau sebut sebagai thaun 'Am, tahun $794 \mathrm{H}$, di damaskus terkena thaun yang luar biasa, para tokoh agama menggerakkan massa untuk bermunajat di tempat terbuka. Hasilnya, thaun semakin merebak. Adapun Istoghasah yang pernah dilakukan pada masa Umar bin Abdul Aziz karena kejadian gempa. Gempa berbeda dengan thaun. Ketika thaun terjadi, kumpulan massa bisa menjadi sarana penyebaran secara massif (Asqalani, 2020).

\section{“Al-Ibāa' 'an Mawāqi' alWabā"', ditulis oleh Idris bin Hisam ad-Din 'Aly al-Badlisy (w. 930 H/1523 M),}

Naskah ini membahas tentang penyakit yang pernah mepandemi di zamannya. Buku ini ditulis tatkala AlBadlisy berangkat dari Konstantin (Turki) menuju Iskandariah (Mesir) yaitu pada tahun 917 H/1511 M, lalu setelah itu dia berangkat menunaikan ibadah haji ke Makkah. Singkat cerita, dia hendak kembali ke Konstantin sebagai menghormati Sultan Salim. Namun dalam perjalanan, tatkala sampai di Syam, dia mendengar bahwa Mesir ditimpa pandemi Tha'un, dengan demikian dia dilarang datang (masuk) ke Mesir. Lalu berikutnya dia pergi ke Istanbul. Rangkaian peristiwa ini mendorongnya untuk menulis buku ini (Butar-Butar, 2020). 
Khazanah Pendidikan Islam, Vol. 3 No. 1: 1 - 9

Bibilografi Sejarah Pandemi Black Death di Mesir pada Abad ke $14 \mathrm{M}$

Ady Fauzi Rahmani

\section{The Black Death in Egypt an England: A Comparative studyoleh StuartJ. Borsch}

Buku ini adalah studi ambisius yang mempertanyakan mengapa dengan krisis demografis yang sama (akibat black death) pertanian di Inggris dapat berkembang pesat, tetapi di Mesir justru merosot. Borsch menolak penjelasan yang menekankan perbedaan antara buday a "Islam" dan Barat, ia juga menolak penjelasan mengenai irigasi dan sistem penanggulangan banjir tahunan sebagai sebabnya. Ia lebih menekankan pada Borsch malah beralih ke perbedaan dalam sistem kepemilikan tanah antara Mesir dan Inggris untuk menjelaskan lintasan pasca-pandemi yang berbeda. Sistem di Mesir dibawah kekuasaan Mamluk, mencegah kepemilikan tanah dalam jumlah besar scara turun temurun. Maka, para tuan tanah lebih memilih keuntungan yang didapat dari pertanian jangka pendek. (S. J. Borsch, 2005)

\section{The Black Death In The Middle East karya Michael W. Dols}

Pada pertengahan abad ke-14, pandemi pandemi yang menghancurkan, umumnya dikenal dalam sejarah Eropa sebagai "Kematian Hitam", melanda benua Eurasia. Buku ini, yang terutama didasarkan pada sumber-sumber Arab, menetapkan sarana penularan dan kronologi penyebaran pandemi penyakit di Timur Tengah. Pengurangan populasi yang berkepanjangan yang dimulai dengan Kematian Hitam sangat penting bagi sejarah sosial dan ekonomi Mesir dan Suriah di akhir Abad Pertengahan. Penyebaran epidemi menunjukkan kehancuran kehidupan manusia yang luar biasa di abad keempat belas, dan serangkaian kambuhnya pandemi sangat memperlambat pertumbuhan penduduk di abad setengah berikutnya, memiskinkan masyarakat Timur Tengah. Reaksi sosial menggambarkan kekuatan nilai-nilai dan praktik tradisional Muslim, organisasi sosial, dan keterpaduan. Penurunan demografis yang tiba-tiba menyebabkan penyesuaian ekonomi jangka panjang dan langsung dalam nilai tanah, gaji, dan perdagangan (Dols, 2019).

\section{Plagues, Wages, and Economic Change in the Islamic Middle East, 700-1500}

Untuk Mesir, diperkirakan bahwa sekitar seperempat hingga sepertiga dari populasi meninggal dan ekonomi berkontraksi tajam mulai tahun 1347. Populasi kemudian terus menurun hingga akhir abad ke-15 dan total penurunan mencapai 40 persen karena kambuhnya pandemi. Namun, pendapatan mereka yang selamat seringkali lebih tinggi (Pamuk \& Shatzmiller, 2014).

\section{Plague in Egypt: Disease biology, history and contemporary analysis: A minireview.}

Black Death berasal dari atau dekat Tiongkok dan menyebar melalui Jalur Sutra atau dengan kapal. Ini telah mengurangi populasi dunia sekira 450 juta menjadi antara 350 dan 375 juta pada tahun 1400. Pandemi ini melanda berbagai negara di Timur Tengah dan menyebabkan depopulasi yang serius dan perubahan permanen baik dalam struktur ekonomi maupun sosial. Saat menyebar ke Eropa Barat, penyakit ini juga memasuki wilayah dari Rusia Selatan. Pada 1347, pandemi mencapai Aleksandria di Mesir, mungkin melalui perdagangan pelabuhan dengan Konstantinopel, dan pelabuhan di Laut Hitam. Kemungkinan kemunculan kembali penyakit membuat Mesir membutuhkan implementasi beberapa tindakan pencegahan (Lotfy, 2015). 


\section{Plague Depopulation and Irrigation Decay in Medieval Egypt}

Penurunan demografis yang disebabkan oleh pandemi di Mesir membuktikan bahwa hasil berbeda secara drastis dari satu tempat ke tempat lain, bergantung pada variabel dependen seperti struktur sosial dan lingkungan. Tetapi ada pelajaran penting yang bisa dipetik dari studi pandemi di masa depan di bidang ini. Misalnya, Mesir berpotensi untuk mengajari kita sesuatu yang baru tentang biologi pandemi. Pembalseman mayat Mesir yang terkenal, telah menghasilkan begitu banyak jenazah yang terawat baik dari zaman kuno, merupakan faktor penting di sini. Banyaknya kuburan berpasir di tengah dua kuburan besar (Qarafatayn, sebutannya) yang melingkari tepi timur Kairo. Kita mungkin menemukan harta karun harta karun yang kaya dan suram dari bukti di beberapa kuburan ini, sisa jaringan lunak serta sisasisa kerangka yang layak untuk dipelajari dengan cermat (S. Borsch, 2016).

\section{Pembahasan}

Ibnu Hajar membedakan thaun dan pandemi. pandemi berasal dari sisa azab orang terdahulu, dan bisa jadi juga serangan setan, adalah thaun. Adapun penyakit yang menyebar di suatu daerah bisa jadi merupakan thaun, bisa jadi hanya pandemi saja (Asqalani, 2020). Dalam kacamata Ibnu Hajar, (w. 852 H/1448 M), salah seorang ulama 3 putrinya yaitu Fathimah, Zeinah dan Gholiyah (dalam riwayat lain dua putrinya yaitu Fathimah dan Aliyah) wafat dalam sebuah tragedi pandemi akibat dampak dari blackdeath, pandemi ini termasuk thaun. Hal itulah yang menjadi salah satu motivasi Ibnu Hajar menulis kitab badzli maun fi fadhli tha'un. Secara garis besar, kitab ini membahas 3 hal, yaitu: (1) tentang penyakit Tha'un. (2) tentang obatobatan. (3) tentang kepustakaan penyakit Tha'un.(Butar-Butar, 2020). Kitab tersebut menerangkan definisi, penyebab, perkiraaan durasi, serta hal yang dapat dilakukan untuk mencegah dan menanggulangi terjadinya tha'un. (nurul Wathoni, 2020).

Maka, Black death yang terjadi di Eropa dan menyebar ke Mesir, bisa jadi merupakan thaun, atau hanya pandemi saja. Ibnu Qayyim berpendapat bahwa para ahli fisik, tidak dapat membuktikan argument mereka yang menentang dalil (yang menyebutkan bahwa pandemi berasal dari azab Allah dan pekerjaan setan). Karena, hanya nabi yang bisa menjelaskan tentang perkara ghaib. Tapi, keyakinan ini bukan untuk menekan ahli fisik membuktikannya. Beliau justru mengajukan koeksistensi dua penjelasan ini dengan alat dan kategori masing-masing (Ragab, 2012).

Meski demikian, pencegahan penyebaran thaun, bisa diterapkan dalam pencegahan pandemi. Salah satunya adalah dengan isolasi kota yang terkena pandemi. Salah satu strategi perlindungan public tertua dan ada di mana-mana. Sistem ini, di barat (Eropa) bermual dari kepanikan penyebaran pandemi black death. Sampai 300 tahun setelah black death, kota-kota besar di Eropa masih menerapkan ini ketika terjadi pandemic (Hidayani, 2020).

Jauh sebelum itu, nabi Muhammad telah memerintahkan untuk tidak masuk ke wilayah yang terkena pandemic atau pandemi. Sebaliknya, Jika pandemi menimpa daerahnya, maka tidak boleh keluar (Mukharom \& Aravik, 2020). Para sejarawan berpendapat bahwa tradisi ini disandarkan pada kpeercayaan terhadap takdir. Muslim tidak boleh lari dari takdir yang telah ditetapkan, meskipun itu kematian (tawakkal). Adz Dzahabi memandang tawakkal ini dengan cara yang berbeda. Beliau memandang perintah itu bisa dijelaskan dengan nilai kesehatan. Beliau berpendapat bahwa tradisi ini melindungi orang-orang dari terkena pandemi, karena 
udara yang tercemar (Algifahmy, 2020). Hal itu selaras dengan pengetahuan medis abad pertengahan yang percaya, bahwa pandemi disebabkan karena polusi udara atau lingkungan sekitarnya. Sebagaimana lingkungan yang rusak di sekitar orang yang sakit, orang yang sehat akan rentan terkena penyakit ketika berdekatan dengan orang yang sakit. Imam Adz Dzahabi, menyampiakan penyebab pandemi, yaitu karena udara yang buruk, hampir mirip dengan pencemaran air (Rustiman, 2020).

\section{SIMPULAN}

Naskah-naskah (manuskrip) yang pernah ditulis oleh para ulama dan dokter Muslim menunjukan bahwa fenomena pandemi penyakit menular (pandemi) sejatinya telah ada dan berulang kali terjadi sepanjang sejarah umat manusia. Terlepas dari pengaruh geografisnya, Kejadian thaun di Mesir yang mengakibatkan depopulasi, serta dampaknya terhadap pengetahuan medis, bangunan ekonomi, bahkan pertanian yang sistem irigasinya terdampak karena ketiadaan pekerja untuk merawatnya, memberikan pelajaran, agar setiap negara perlu membuat sebuah protokol khusus menghadapi thaun. Penelitian vaksin dan obat-obatan pennyakit yang menyebabkan pandemic, adalah langkah yang harus dilakukan. Namun, proses menemukan penyakitnya, menguji vaksin dan obatnya, sampai dinya takan layak digunakan sangatlama. Selamaitu, negara perlu mengeluarkan Kebijakan dalam keadaan darurat thaun, yaitu dengan (1) pembatasan social bagi yang sehat, (2) karantina dan penyembuhan bagi yang terkena (3) memenuhi kebutuhan rakyat yang kehilangan pekerjaan, dengan cara (a) mensuplai makanan dan kebutuhan pokok darurat dan (b) mendukung usaha kreatif dari dampak thaun dengan membuka kesempatan, memberi bantuan modal, serta penyederhanaan birokrasi dan aturan untuk masyarakat kesulitan itu menjadi peluang usaha. (4) menjaga aktifitas pendidikan tetap terjaga dengan (a) pemberlakuan pembelajaran di rumah masinng masing dengan segenap aturan dan kurikumulnya, (b) penyediaan media dan metodenya.(5) mendukung paraahli medis dengan regulasi dan aliran dana untuk mencari obat penyakit tahun tersebut. Setelah keputusan dibuat pem erintah, setiap komponen menerima dan melaksanakan keputusan tersebutsesuai dengan perannya masing-masing.

\section{DAFTAR PUSTAKA}

Algifahmy, A. F. (2020). MEANINGFUL LEARNING COURSE SIRAH NABAWIYAH (DOWNSTREAM OF ONLINE LEARNING). Historis: Jurnal Kajian, Penelitian Dan Pengembangan Pendidikan Sejarah, 5(2), 107-112.

Asqalani, I. H. A. '. (2020). badzlul Maun fi Fadhli thaun. Terjmahan Fuad Syaifudin nur (1st ed.). Turos Pustaka.

Batutah, I. (1987). Rihlah ibnu Battutah (Thob'at Ul).

Bistara, R. (2020). Islam dan Sains Menurut Sayyed Nasr Nasr. Prosiding Konferensi Integrasi Interkoneksi Islam Dan Sains, 2, 113-117.

Blossfeld, H.-P., Hamerle, A., \& Mayer, K. U. (2014). Event history analysis: Statistical theory and application in the social sciences. Psychology Press.

Borsch, S. (2016). Plague Depopulation and Irrigation Decay in Medieval Egypt (Issue September). https://doi.org/10.13140/RG.2.2.12151.21922

Borsch, S. J. (2005). The Black Death in Egypt and England: a comparative study.

Butar-Butar, A. J. R. (2020). Kepustakaan di Dunia Islam. 1-110.

Conrad, L. I. (1970). Tha ' un dan Waba 'Konsep Plague dan Pestilence dalam Awal Periode Islam (Issue 1969).

Dols, M. W. (2019). The black death in the middle east. Princeton University Press. 
DOLS, M. W. (PRINCETON). (1977). THE BLACK DEATH IN THE MIDDLE EAST (1ST ed.). Princeton University Press.

Hidayani, W. R. (2020). Epidemiologi. Deepublish.

Khaldun, I. (1973). Muqaddimah. (Beirut: Dar Al-Fikr).

Kuhn, T. S., \& Hawkins, D. (1963). The Structure of Scientific Revolutions. American Journal of Physics, 31(7), 554-555.https://doi.org/10.1119/1.1969660

Lotfy, W. M. (2015). Plague in Egypt : Disease biology, history and contemporary analysis : A minireview. Journal of Advanced Research, 6(4), 549-554. https://doi.org/10.1016/j.jare.2013.11.002

Mukharom, M., \& Aravik, H. (2020). Kebijakan Nabi Muhammad Saw Menangani Wabah Penyakit Menular dan Implementasinya dalam Konteks Penanggulangan Coronavirus Covid-19. SALAM: Jurnal Sosial Dan Budaya Syar-I, 7(3), 239-246.

Nurhayati, N. (2016). Kesehatan dan Perobatan dalam Tradisi Islam: Kajian Kitab Shahih AlBukhârî. AHKAM: Jurnal Ilmu Syariah, 16(2), 223-228. https://doi.org/10.15408/ajis.v16i2.4452

nurul Wathoni, L. M. (2020). Tafsir Virus (Fauqa Ba'Ūdhah): Korelasi Covid-19 Dengan Ayat-Ayat Allah. El-'Umdah, 63-84.

Pamuk, S., \& Shatzmiller, M. (2014). Plagues, Wages, and Economic Change in the Islamic Middle East, 700-1500. The Journal of Economic History, 74(2004), 196-229. https://doi.org/10.1017/S0022050714000072.

Ragab, A. (2012). Prophetic traditions and modern medicine in the Middle East: resurrection, reinterpretation, and reconstruction. Journal of American Oriental Society, 132(4), 657-673.

Rustiman, U. (2020). NASKAH KUNO ARAB ATH THIBBUN NABAWI; MODEL KEBIJAKAN RASULULLAH SAW DALAM IKHTIYAR MENGHADAPI WABAH KARYAIMAM ADZ DZAHABI ABAD KE-13.Al-Ibanah, 5(2), 1-19.

Thohir, A., \& Sahidin, A. (2019). Filsafat Sejarah Profetik, Spekulatif dan Kritis (cetakan ke). PRENADAMEDIA GROUP. 